University of Montana

ScholarWorks at University of Montana

$4-2008$

\title{
Novel Weapons: Invasive Plant Suppresses Fungal Mutualists in America but not in its Native Europe
}

\author{
Ragan M. Callaway \\ University of Montana - Missoula, Ray.Callaway@mso.umt.edu \\ Don Cipollini \\ Kathryn Barto \\ Giles C. Thelen \\ STeven G. Hallett \\ See next page for additional authors
}

Follow this and additional works at: https://scholarworks.umt.edu/biosci_pubs

Part of the Biology Commons

Let us know how access to this document benefits you.

\section{Recommended Citation}

Callaway, Ragan M.; Cipollini, Don; Barto, Kathryn; Thelen, Giles C.; Hallett, STeven G.; Prati, Daniel;

Stinson, Kristina; and Klironomos, John, "Novel Weapons: Invasive Plant Suppresses Fungal Mutualists in America but not in its Native Europe" (2008). Biological Sciences Faculty Publications. 224.

https://scholarworks.umt.edu/biosci_pubs/224

This Article is brought to you for free and open access by the Biological Sciences at ScholarWorks at University of Montana. It has been accepted for inclusion in Biological Sciences Faculty Publications by an authorized administrator of ScholarWorks at University of Montana. For more information, please contact

scholarworks@mso.umt.edu. 


\section{Authors}

Ragan M. Callaway, Don Cipollini, Kathryn Barto, Giles C. Thelen, STeven G. Hallett, Daniel Prati, Kristina Stinson, and John Klironomos 


\title{
NOVEL WEAPONS: INVASIVE PLANT SUPPRESSES FUNGAL MUTUALISTS IN AMERICA BUT NOT IN ITS NATIVE EUROPE
}

\author{
Ragan M. Callaway, ${ }^{1,7}$ Don Cipollini, ${ }^{2}$ Kathry Barto, ${ }^{2}$ Giles C. Thelen,,${ }^{1}$ Steven G. Hallett,${ }^{3}$ \\ Daniel Prati, ${ }^{4,8}$ Kristina Stinson, ${ }^{5}$ and John Klironomos ${ }^{6}$ \\ ${ }^{1}$ Division of Biological Sciences, University of Montana, Missoula, Montana 59812 USA \\ ${ }^{2}$ Department of Biological Sciences, Wright State University, Dayton, Ohio 45435 USA \\ ${ }^{3}$ Department of Botany and Plant Pathology, Purdue University, West Lafayette, Indiana 47907 USA \\ ${ }^{4}$ Department of Community Ecology, UFZ Centre for Environmental Research, D-06120 Halle, Germany \\ ${ }^{5}$ Harvard Forest, Harvard University, Petersham, Massachusetts 01366 USA \\ ${ }^{6}$ Department of Integrative Biology, University of Guelph, Guelph, Ontario N1G 2 W1 Canada
}

\begin{abstract}
Why some invasive plant species transmogrify from weak competitors at home to strong competitors abroad remains one of the most elusive questions in ecology. Some evidence suggests that disproportionately high densities of some invaders are due to the release of biochemicals that are novel, and therefore harmful, to naïve organisms in their new range. So far, such evidence has been restricted to the direct phytotoxic effects of plants on other plants. Here we found that one of North America's most aggressive invaders of undisturbed forest understories, Alliaria petiolata (garlic mustard) and a plant that inhibits mycorrhizal fungal mutualists of North American native plants, has far stronger inhibitory effects on mycorrhizas in invaded North American soils than on mycorrhizas in European soils where $A$. petiolata is native. This antifungal effect appears to be due to specific flavonoid fractions in $A$. petiolata extracts. Furthermore, we found that suppression of North American mycorrhizal fungi by $A$. petiolata corresponds with severe inhibition of North American plant species that rely on these fungi, whereas congeneric European plants are weakly affected. These results indicate that phytochemicals, benign to resistant mycorrhizal symbionts in the home range, may be lethal to naive native mutualists in the introduced range and indirectly suppress the plants that rely on them.
\end{abstract}

Key words: allelopathy; anti-fungal compounds; arbuscular mycorrhizae; biochemistry; biogeographical comparisons; exotic invasion; fungi; indirect interactions; novel weapons.

\section{INTRODUCTION}

One of the most perplexing questions in ecology is how some species, when moved to new ranges by humans, suppress other species and become far more abundant than in their native ranges (Elton 1958, Blossey and Nötzold 1995, Hierro et al. 2005). There are many hypotheses for such invasive success, but all hypotheses converge on the need for a biogeographic explanation; either the invader must face much weaker opposition from other species abroad than at home or the invader must have stronger effects on species abroad than at home. Interactions between plants and their consumers (Keane and Crawley 2002, DeWalt et al. 2005, van der Putten et al. 2005) and among plants (Callaway and Aschehoug 2000, Vivanco et al. 2004) have received some explicit biogeographic attention, and other comparative studies demonstrate that highly aggressive invasive exotic plants are "more likely to have potent secondary compounds that have not been

Manuscript received 3 June 2007; revised 8 August 2007; accepted 15 August 2007. Corresponding Editor: G. S. Gilbert.

${ }^{7}$ E-mail: ray.callaway@mso.umt.edu

8 Present address: Institute for Biochemistry and Biology, University of Potsdam, D-014469 Potsdam, Germany. reported from North American native plants" than exotic species that are not considered invasive (Cappuccino and Arnason 2006). The idea that some invaders may succeed because they possess novel biochemicals that provide them with an advantage against naïve species has been coined the "novel weapons hypothesis" (Callaway and Ridenour 2004, Callaway et al. 2005).

Evidence for such novel weapons has focused on phytotoxic interactions among plants (Rabotnov 1982, Callaway and Aschehoug 2000, Mallik and Pellisier 2000, Bais et al. 2003, Vivanco et al. 2004, Blair et al. 2005, Thorpe 2006), and in the novel biochemical effects of an invader on mutualist fungi (Stinson et al. 2006). However, recent studies suggest that interactions between microbes and plants may be particularly important for understanding plant invasions (van der Putten et al. 1988, Klironomos 2002, Reinhart et al. 2003, Beckstead and Parker 2004, Callaway et al. 2004). Soil microbes have crucial detrimental and beneficial effects on plants through pathogenic effects, root-fungus mutualisms and by driving the nutrient cycles on which plants depend (Johnson et al. 1997, Packer and Clay 2000, Torsvik and Øvreås 2004). However, not all plants are equally dependent on particular microbial processes. Similarly, plants can have powerful but species-specific 
effects on soil microbes (Vitousek et al. 1987, Philippot and Germon 2005). These plant-microbe relationships may be vulnerable to disruption through the novel biochemistry of invaders (Callaway et al. 2005). Here we explored the novel weapons hypothesis in the context of invasive plants and arbuscular mycorrhizae.

Alliaria petiolata (Bieb.) Cavara \& Grande), a European invader of North American forests, suppresses the growth of North American species by disrupting mutualistic associations between native canopy tree seedlings and belowground arbuscular mycorrhizal (AM) fungi (Stinson et al. 2006, also see Roberts and Anderson 2001). But if suppressing soil fungal mutualists is to explain the transformation of $A$. petiolata into a far more dominant species in its new range, then these effects must be stronger in North America than in Europe. We compared the effects of $A$. petiolata, and biochemical extracts from $A$. petiolata, on mutualistic associations between plants and AM fungi in European soils to the effects of these factors on mutualisms in North American soils. We addressed the following specific questions: (1) Is A. petiolata more toxic to AM fungi in North America than in Europe? (2) Are North American mycorrhizal plants more negatively impacted by $A$. petiolata than those that co-occur with $A$. petiolata in Europe? (3) Are non-mycorrhizal plants in North America less negatively impacted by $A$. petiolata in North America? (4) What is the biochemical basis of $A$. petiolata toxicity to AM fungi, and does this differ between continents?

\section{Methods}

Study species

Alliaria petiolata (garlic mustard) is a sexually reproducing, obligate biennial forb native to Europe that aggressively invades forest habitats in North America. In its native range, it is found in forest edges and other semi-shaded habitats as well as forest understory, but does not aggressively colonize or dominate in these habitats (Clapham et al. 1952). Seedlings emerge in early spring and progress to evergreen rosettes during the first year. Flowers are borne in late spring on one or more stalks of the secondyear plants, and mature into elongated siliques. Seeds may require overwintering for germination (Baskin and Baskin 1992, Nuzzo 2000). Since its arrival into the northeastern United States in the 1800s (Clapham et al. 1952, Nuzzo 1991) A. petiolata first spread gradually, then underwent a series of rapid population explosions over the past two to three decades (Dhillion and Anderson 1999, Nuzzo 2000, Meekins and McCarthy 2001). In North America, A. petiolata frequently forms dense, monospecific stands that dominate native plant communities within a variety of habitats, including forest edges, floodplains, and forest understory (Nuzzo 1991, Stinson et al. 2006). It is now widespread across the Eastern Seaboard, from Ontario to the Carolinas, extending to the Midwest and more recently, as far west as California and Oregon (Welk and Schubert 2002).

\section{Growth experiment}

We collected 8-18 L of soil from each of four sites in North America (USA) and two sites in Europe. In Vermont (collected March 2004 in Bennington, 42 52.3' $\mathrm{N}, 73^{\circ} 11.3^{\prime} \mathrm{W}$ ), Oregon (collected April 2004 in Portland, $45^{\circ} 30.3^{\prime} \mathrm{N}, 122^{\circ} 41.4^{\prime} \mathrm{W}$ ), and Massachusetts (collected February 2004 in Harvard Forest, 42 31.4' $\mathrm{N}, 72^{\circ} 11.1^{\prime} \mathrm{W}$ ), soil was collected from deciduous forest (dominated by Acer and Quercus) understories not inhabited by $A$. petiolata, but within $100 \mathrm{~m}$ of $A$. petiolata populations. In Montana, USA (collected April 2004 in Missoula, 46 53.0' N, 113 58.3' W), soil was collected from a deciduous riparian forest (dominated by Populus and Acer) understory not inhabited by $A$. petiolata and in a part of North America in which $A$. petiolata does not occur. In Germany (collected January

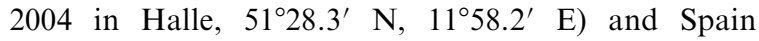
(collected April 2004 in $42^{\circ} 49.2^{\prime} \mathrm{N}, 1^{\circ} 17.3^{\prime} \mathrm{W}$ ), soil was collected from deciduous forest (dominated by Acer and Quercus) understories not invaded by $A$. petiolata, but within $100 \mathrm{~m}$ of $A$. petiolata populations. Soil was slowly air-dried immediately after collection and stored until used in the experiment. On 4 May 2004, the soil from each region (we use "region" to designate each of the six sites from which soil was collected and "continent" to designate comparisons of North America and Europe) was divided in half and each half was divided into three 2.8-L pots. For some sites from which not enough soil was collected, pots were not filled completely. To culture the experimental soils (see Klironomos 2002), root cuttings were collected from overwintering rosettes of Alliaria in March 2004 in a forest in central Michigan (Kellogg Biological Station, $42^{\circ} 19.3^{\prime} \mathrm{N}, 85^{\circ} 18.2^{\prime} \mathrm{W}$ ), USA, over $1000 \mathrm{~km}$ from any soil collection site. These cuttings were surface sterilized with a solution of $5 \%$ bleach and transplanted into half of the pots used for each region, and then were grown to maturity in each pot. At least one plant in each pot flowered. The other (control) pots were filled with soil, but no plants were put in them. Plants in this experiment were grown in a single greenhouse with no-plant controls randomly intermixed with the planted pots and watered exactly as the planted pots. Greenhouse temperatures were kept between $15^{\circ}-28^{\circ} \mathrm{C}$. Natural light was supplemented by Metal Halide bulbs, and total photosynthetically active radiation (PAR) during the day remained above $1200 \mu \mathrm{mol} \cdot \mathrm{m}^{-2} \cdot \mathrm{s}^{-1}$, which would not limit a shade tolerant species such as $A$. petiolata (Meekins and McCarthy (2000).

In October 2004, 185 days after planting, $A$. petiolata plants were removed from pots. Keeping all sites and $A$. petiolata-cultured and control (no $A$. petiolata) treatments separate, aliquots from soil were transferred to $525-\mathrm{mL}$ pots. For each of the $525-\mathrm{mL}$ pots, $50 \mathrm{~mL}$ of sterile silica sand was placed at the bottom, $150 \mathrm{~mL}$ of a 
50:50 mix of sterile silica sand and soil was placed on top of the pure sand, and $250 \mathrm{~mL}$ of pure soil was placed on top of the soil/sand mixture. These pots were transferred to a larger greenhouse at the University of Montana (Missoula, Montana, USA) with temperature and light conditions similar to the first greenhouse. As for the arrangement of pots during the period in which soils were trained with $A$. petiolata, pots with the different plant and soil combinations were randomly mixed within the bench space used for the experiment.

For each location where we collected soil, we acquired seeds from 10-14 plant species native to that region. However, poor germination reduced the total number of species used to 7-10 species per region. To remedy low species numbers, we used Pseudoroegneria spicata and Festuca idahoensis from Montana in Massachusetts and Vermont soils. The species used and their sources are listed in Table 1. Our goal was biogeographic comparisons among some genera that are commonly mycorrhizal; and similar comparisons among other genera that are not (e.g., Carex). Poor germination of some of the non-mycorrhizal species reduced our final number to six North American species-soils combinations, and two European species-soils combinations.

For each species, we prepared 10 replicates of the 525$\mathrm{mL}$ pots for $A$. petiolata-cultured soils and 10 replicates for the control (no A. petiolata) soils. We only planted species from a region in soils from the same region (with the exception of $P$. spicata and $F$. idahoensis, see previous paragraph) and no species and soils were crossed among regions. Within three days of transferring soils from the $2.4-\mathrm{L}$ pots to the $525-\mathrm{mL}$ pots, 10 seeds of a species were planted in each pot (12 and 13 October 2004). At the same time, aliquots of soils from the treatment and the control pots were shipped on dry ice to the University of Guelph, Ontario, Canada, where they were analyzed for spore density, spore viability, and infectivity (see following paragraph). Seedling emergence was monitored until 11 November 2004, but all germinants after the first germinant were removed so that only one individual grew per pot. All seeds had received four weeks of cold stratification and were germinated in similar temperatures, light, and moisture conditions in the experiment. The effects of training soil microbial communities can be confounded by the effects of training on soil nutrients. To ameliorate the problem of differential nutrient depletion by training some soils and not others, plants in our experiments were watered every two weeks with $200 \mathrm{~mL}$ of one-quarter-strength Hoagland's solution modified by the addition of phosphorus as inositol hexaphosphate. This form is not directly available for uptake by plants. Seedlings were harvested 15-31 December 2004, but species in the same genus from all six regions were harvested on the same day to minimize bias towards any continent, region, or treatment. Seedlings were dried at $60^{\circ} \mathrm{C}$ and weighed for total biomass. A subsample of roots was
TABLE 1. HPLC flow conditions for flavonoid and alliarinoside analysis.

\begin{tabular}{lcc}
\hline \hline Time $(\mathrm{min})$ & Water $(\%)$ & Acetonitrile $(\%)$ \\
\hline Initial conditions & 95 & 5 \\
5 & 90 & 10 \\
20 & 70 & 30 \\
30 & 70 & 30 \\
33 & 95 & 5 \\
38 & 95 & 5 \\
\hline
\end{tabular}

sent to the University of Guelph to determine mycorrhizal colonization (see following section).

\section{AM fungi analysis}

AM fungal spores were extracted directly from the soil using a wet-sieving/centrifugation method (Klironomos et al. 1993), and counted under $20 \times$ magnification. Viability of those spores was assessed after placing them in iodonitrotetrazolium solution $(1 \mathrm{mg} / \mathrm{mL})$ for 48 h (Carvalho et al. 2004). Mycorrhizal infectivity of the soil was assessed after growing leek (Allium porrum, Liliaceae) in the soil for four weeks, staining the roots using Chlorazol Black E (Brundrett et al. 1984), and then measuring the percentage of root colonization (McGonigle et al. 1990).

\section{Soil microbial community analysis}

Soil samples for microbial community analysis were taken from the same trained soil samples that were used for plant response experiments. Soil microbial communities were characterized using denaturing gradient gel electrophoresis of PCR-amplified small subunit ribosomal RNA genes (PCR-DGGE; Muyzer et al. 1996, Kim-Jong et al. 1999). DNA was extracted from soil samples using a bead-beating technique using 0.5 -g of sample per extraction with a FastDNA SPIN kit (QBiogene, Irvine, California, USA). PCR reactions utilized a touchdown protocol where the annealing temperature was decreased by $1^{\circ} \mathrm{C}$ each cycle in order to maintain the highest level of stringency in the first few reactions (Don et al. 1991), and one primer was modified with a 40-bp GC clamp in order to arrest the migration of amplified rDNA fragments during electrophoresis (Sheffield et al. 1989). Gradients were formed with an agitated CBS gradient former and amplified DNA products were separated by electrophoresis on a CBS2201 DGGE apparatus (CBS Scientific, Del Mar, California, USA). A small fragment (196 bp) of the V3 variable region of the bacterial $16 \mathrm{~S}$ rDNA was amplified using the universal bacterial primers (Muyzer et al. 1996). The polymerase chain reaction (PCR) cycle was 5 min at $95^{\circ} \mathrm{C}$, and then 11 cycles of $30 \mathrm{~s}$ at $93^{\circ} \mathrm{C}, 30 \mathrm{~s}$ at $65^{\circ} \mathrm{C}, 30 \mathrm{~s}$ at $72^{\circ} \mathrm{C}$, and then 19 cycles of $30 \mathrm{~s}$ at $93^{\circ} \mathrm{C}, 30$ $\mathrm{s}$ at $55^{\circ} \mathrm{C}, 30 \mathrm{~s}$ at $72^{\circ} \mathrm{C}$, with a final extension of $15 \mathrm{~min}$ at $72^{\circ} \mathrm{C}$. The fungal ribosomal internal transcribed spacer (ITS) region (550 bp) was amplified using the primers of White et al. (1990). The PCR cycle was $5 \mathrm{~min}$ at $95^{\circ} \mathrm{C}$, 
and then 11 cycles of $30 \mathrm{~s}$ at $95^{\circ} \mathrm{C}, 45 \mathrm{~s}$ at $65^{\circ} \mathrm{C}, 2$ min at $72^{\circ} \mathrm{C}$, and then 19 cycles of $30 \mathrm{~s}$ at $95^{\circ} \mathrm{C}, 45 \mathrm{~s}$ at $55^{\circ} \mathrm{C}, 2$ $\min$ at $72^{\circ} \mathrm{C}$, with a final extension of $5 \mathrm{~min}$ at $72^{\circ} \mathrm{C}$. PCR products were separated on DGGE gels as follows: bacterial $16 \mathrm{~S}$ at $10 \% \mathrm{~T}, 19: 1$ [5\%C] acrylamide/bisacrylamide, $160 \mathrm{~V}, 18 \mathrm{~h}, 60^{\circ} \mathrm{C}, 35-75 \%$ denaturant gradient; and fungal ITS at $8 \% \mathrm{~T}, 37.5: 1$ [2.6\% $]$ acrylamide/bis-acrylamide, $140 \mathrm{~V}, 18 \mathrm{~h}, 60^{\circ} \mathrm{C}, 30-65 \%$ denaturant gradient. DNA in gels was stained with SYBR Green and photographed over a UV transilluminator. Band pixel intensity in photographs was normalized to total lane intensity and analyzed with the aid of a band recognition program (Quantity One; BioRad, Hercules, California, USA), and bands were then scored as having an intensity of $0,1,2,3$, or 4 , where a score of zero represented a band that was absent from the sample, but present in the composite lane, which was created as a reference that comprised all the bands found in the lanes from the test samples representing the total taxon richness. A score of four was given to the brightest band on the gel. Similarity coefficients between paired samples were calculated from common bands (bands migrating the same distance on a gel in different samples) and unique bands (bands present in one sample but absent in the other) using a modification of Sorenson's index of similarity (Sorenson 1948): $C_{\mathrm{s}}=(2 j+k) /(a+b)$, where $C_{\mathrm{s}}$ represents Sorenson's index of similarity, $a$ is the number of bands in sample A, $b$ is the number of bands in sample B, $j$ is the number of bands of the same intensity common to samples $\mathrm{A}$ and $\mathrm{B}$, and $k$ is the number of bands of different intensity common to samples A and B. Pairwise similarity coefficients were generated for all possible sample pairs to generate a matrix showing the degree of similarity among all samples. Comparisons of microbial diversity were made using the Shannon-Weaver diversity index and community evenness index. In this case, banding patterns for each sample were compared against a composite profile representing the sum of bands found in all the samples. $H=(C / N)(N \cdot \log N-$ $\left.\sum n_{i} \cdot \log n_{i}\right)$, where $H$ represents the Shannon Weaver Index, $C=2.3, N$ is total intensity of all bands, and $n_{i}$ is the intensity of $i$ th band; and $e=H / \log (S)$, where $e$ represents the community evenness index, and $S$ is the total number of bands.

\section{Plant extract experiment}

To identify potential biochemical drivers of biogeographic differences in AM inhibition by $A$. petiolata, we isolated fractions enriched in flavonoids or glucosinolates from fresh leaf tissue of $A$. petiolata plants collected from a forest in southwestern Ohio, USA (Wright State University, $39^{\circ} 48^{\prime} \mathrm{N}, 84^{\circ} 1^{\prime} \mathrm{W}$ ). Production of glucosinolates in roots and leaves is well known in A petiolata and other plants in the Brassicaceae, and these measurements were intended to determine if some of the same flavonoids present in leaves and roots of $A$. petiolata plants could also be present in root exudates.
Leaf tissue was boiled in ethanol, then filtered, dried, and defatted with hexane (modified from Haribal and Rewick 2001). The dried extract was dissolved in water, and then partitioned with $n$-butanol to isolate flavonoids and alliarinoside, while the charged glucosinolates remained in the water. Both extracts were dried and redissolved in water. Fractionated extracts were characterized using high performance liquid chromatography (HPLC) to verify locations of compounds. Flavonoids and alliarinoside were analyzed as in Cipollini et al. (2005), but with the flow conditions shown in Table 1 . Glucosinolates were analyzed as described by Kiddle et al. (2001) using a Phenomenex Luna C18 $(150 \times 4.6$ $\mathrm{mm}, 5 \mu \mathrm{m}$; Torrance, California, USA) column and a Waters 2690 HPLC system (Milford, Massachusetts, USA) equipped with a photodiode array detector, with a flow rate of $1 \mathrm{~mL} / \mathrm{min}$.

Ideally, dosages in allelopathy studies should be equivalent to levels found in field soil. However, there are no published reports of $A$. petiolata metabolite levels in soil, and we have been unable to quantify field levels as yet. The related species, Brassica napus, has glucosinolate levels of 14-20 $\mu \mathrm{mol} / \mathrm{g}$ leaf tissue (Gardiner et al. 1999, Morra and Kirkegaard 2002). Isothiocyanates, which are the breakdown products of glucosinolates, reach levels of 40-75 nmol/g in soils following incorporation of B. napus plant material (Moora and Kirkegaard 2002). Assuming that a similar relationship exists for $A$. petiolata, we estimated that soil levels should be $\sim 300$ times less than levels in the leaves and diluted extracts accordingly, to give 0.0033 gram leaf equivalents (gle) per gram of soil. The lowest dose used to show allelopathic effects of $A$. petiolata in the past was 0.05 gle/mL extract (Roberts and Anderson 2001, Stinson et al. 2006), which is an order of magnitude higher than the dose we used. McCarthy and Hanson (1998) used doses as low as $0.001 \mathrm{gle} / \mathrm{mL}$ extract, but only found inhibitory effects at $0.1 \mathrm{gle} / \mathrm{mL}$ extract. Although our choice of dosage is based on data from a separate species, we believe it is more ecologically relevant than the higher doses used in earlier studies.

Extracts were applied as either flavonoid, glucosinolate, or mixed fractions to soils in the laboratory at the University of Montana. Because of the low European replication in the initial experiment, in this experiment we used soils from six sites in North America and six sites in Europe. Soils used included three from the first experiment in North America (Oregon, Vermont, Massachusetts) and two from Europe (Germany and Spain). We collected soils from three new regions in North America (Minnesota $\left[44^{\circ} 10.5^{\prime} \mathrm{N}, 93^{\circ} 58.4^{\prime} \mathrm{W}\right]$, Wisconsin $\left[44^{\circ} 52.5^{\prime} \mathrm{N}, 91^{\circ} 41.2^{\prime} \mathrm{W}\right]$, and Indiana $\left.\left[39^{\circ} 11.4^{\prime} \mathrm{N}, 86^{\circ} 30.5^{\prime} \mathrm{W}\right]\right)$, and four new regions in Europe (Hungary $\left[47^{\circ} 37.5^{\prime} \mathrm{N}, 18^{\circ} 19.2^{\prime} \mathrm{E}\right]$, Romania $\left[47^{\circ} 10.2^{\prime} \mathrm{N}, 27^{\circ} 36.3^{\prime} \mathrm{E}\right]$, the Czech Republic [ $48^{\circ} 46.1^{\prime} \mathrm{N}$, $\left.14^{\circ} 18.1^{\prime} \mathrm{E}\right]$, and France $\left.\left[44^{\circ} 50.5^{\prime} \mathrm{N}, 0^{\circ} 28.0^{\prime} \mathrm{W}\right]\right)$. As before, these soils were dried slowly at room temperature and stored dry until use. On 2 February 2006, 3 gm 
FIG. 1. Effect of Alliaria petiolata pre-culturing on the density, viability, and infectivity of arbuscular mycorrhizal fungal spores in North American and European soils. Bars show the percentage of increase or decrease of soils in which $A$. petiolata had been grown relative to control soils without $A$. petiolata. Asterisks represent statistical significance following separate $t$ tests, with a sequential Bonferroni correction for multiple tests, of $A$. petiolata-cultured and non- $A$. petiolata cultured soil $(P<0.02)$. Abbreviations are: ESP, Spain; DEU, Germany; OR, Oregon; MA, Massachusetts; VT, Vermont; and MT, Montana.

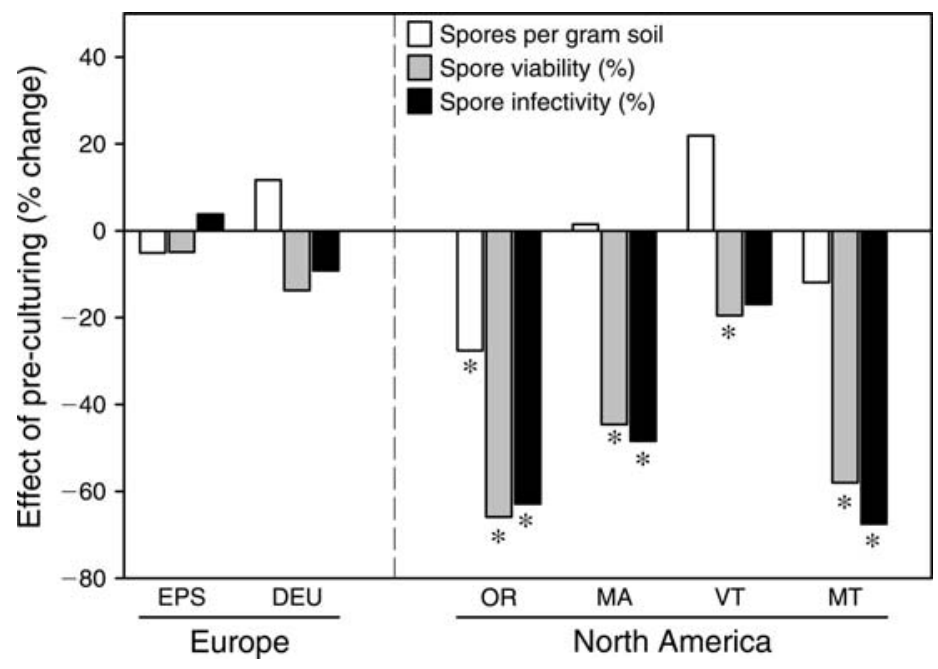

of soil from each region was placed into each of $2015-$ $\mathrm{mL}$ centrifuge tubes (total $n=240$ ). For each region, five samples each were treated with the flavonoid fraction, the glucosinolate fraction, and both glucosinolate and flavonoid fractions to give a final dose of 0.0033 gle per gram of soil. Each treatment was applied in $1.5 \mathrm{~mL}$ of water, and tubes were centrifuged for $15 \mathrm{~s}$ to spread the solution throughout the $3 \mathrm{gm}$ of soil. On 14 February
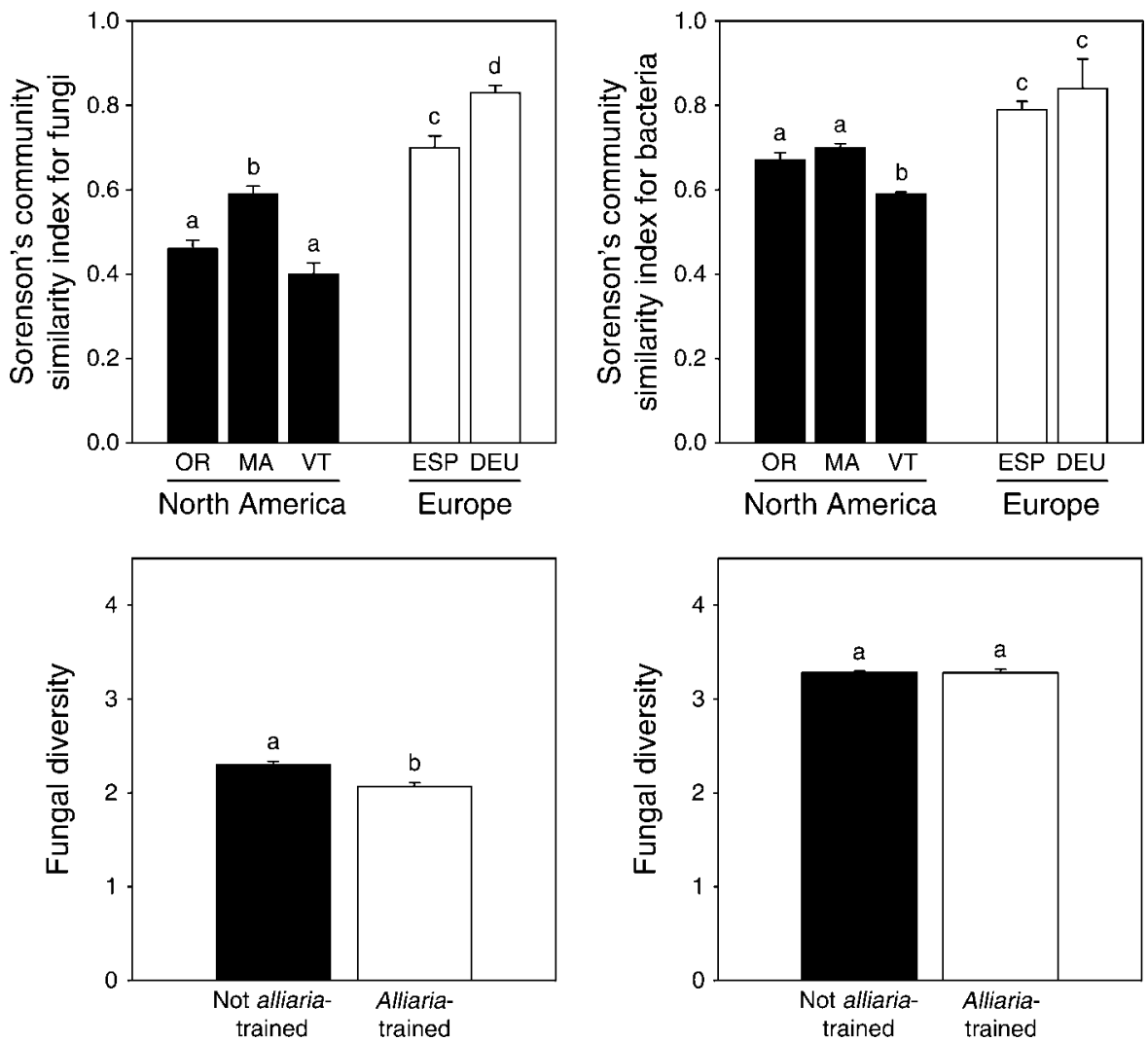

FIG. 2. Comparison of microbial communities in soils from North America and Europe following training by Alliaria petiolata or left untrained from banding patterns on denaturing gradient gels separating microbial taxa based on sequence polymorphism in small subunit ribosomal RNA fragments. Sorenson community index measures the degree of similarity of soil microbial communities between trained and untrained samples. Diversity of microbial communities measured using Shannon-Weaver Diversity Index. Error bars show 1 SE. Bars with the same letter are not significantly different $(P=0.01)$. Means separations by Duncan's multiple-range test. See Fig. 1 for abbreviations. 


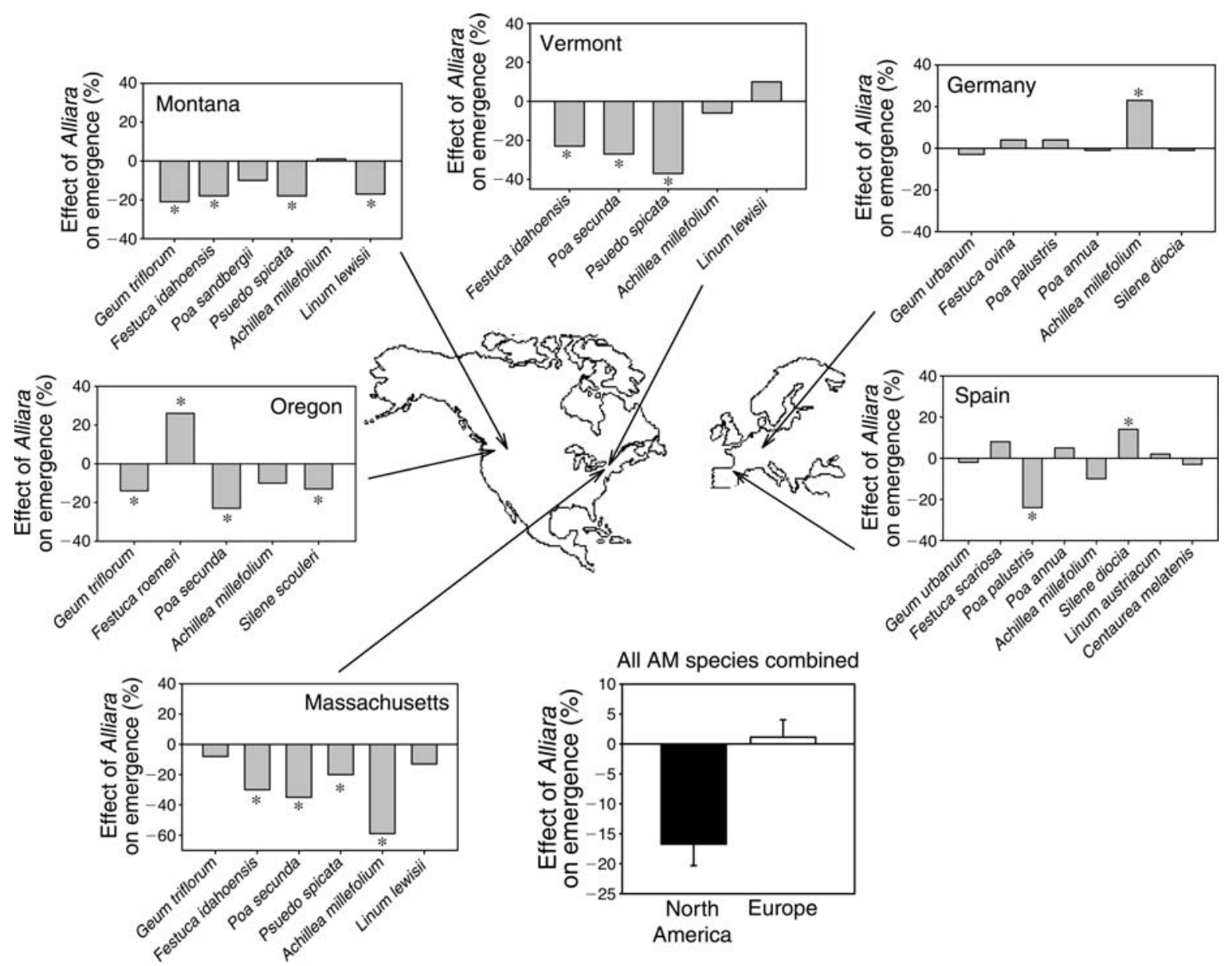

FIG. 3. Effect of pre-culturing soil with Alliaria petiolata on the emergence of arbuscular mycorrhizal (AM) plant species from soil collected at four sites in North America and from two sites in Europe. Each panel shows the results for soils from a particular region and for plant species native to that region. Bars represent the mean proportional change in seedling emergence measured in A. petiolata-cultured soils compared to control soils in which $A$. petiolata was not grown. For each species, $n=10$ pots for the control and $n=10$ pots for the treatment. Each pot was planted with five seeds and the mean emergence per pot was the variable used for statistical analysis. In an ANOVA with the mean for each species at each region used as a replicate; for continent, $F_{1,4}=$ 3.009, $P=0.158$; for treatment, $F_{1,4}=25.901, P=0.007$; for continent $\times$ treatment, $F_{1,4}=30.228, P=0.005$. Asterisks denote significant differences among treatment and control for individual species as determined by separate $t$ tests, followed by a sequential Bonferroni correction for multiple tests, using the mean of five seeds per pot as the replicate, $P<0.00125$ ).

2006, these soils were analyzed for AM spore viability at the University of Guelph (see Methods: AM fungi analysis for methods).

\section{Statistical analysis}

Data were analyzed with mixed-model analysis of variance (ANOVA) using the software R, version 2.1.0 (R Development Core Team 2004). Continent and treatment were considered fixed factors, whereas region and species were nested within continent and treated as random factors. The effects of continent and continentby-treatment interaction were tested against the region and region-by-treatment interaction, respectively. This represents a more conservative approach for testing differences between continents than using species as error term because it treats sites from which soil was collected as independent units of replication.

\section{RESULTS}

Pre-culturing soils with $A$. petiolata caused no differences in the spore density of AM fungi between continents, but the viability and infectivity of these AM spores from North American soils were reduced much more than those from Europe (Fig. 1). Pre-culturing North American soils with $A$. petiolata resulted in significantly lower viability $(-20 \%$ to $-66 \%)$ and infectivity $(-16 \%$ to $-68 \%)$ of AM fungal spores from four different regions of North America. In contrast, $A$. petiolata had no significant effect on the viability and infectivity of AM fungi from two regions of Europe where $A$. petiolata occurs naturally. These results suggest that AM fungi, co-occurring with $A$. petiolata are tolerant to this plant's biochemistry, while AM fungi beyond A. petiolata's native range are not. Culturing 
North American soils with $A$. petiolata also caused larger compositional shifts in soil fungal and bacterial communities than did culturing European soils with $A$. petiolata, and significantly decreased fungal species diversity in North American soils, but not in European soils (Fig. 2).

The reduction of AM fungal spore viability and infectivity in North American soils, but not in European soils, corresponded with biogeographical differences in the emergence and growth of mycorrhizal plant species from the two continents (Fig. 3). In A. petiolata-cultured soils from the four North American regions, the emergence of seedlings of mycorrhizal plant species (Table 2) from those same regions (all regions and all species combined), or from nearby regions of North America, was reduced by $16.7 \% \pm 3.6 \%$. Alliaria petiolata-culturing of soils from two regions of Europe (both regions and all species combined) had no effect on seedling emergence of species from the same areas from which soils were collected. Of the 23 combinations of North American mycorrhizal plant species and North American soils in our experiments, seedling emergence in 13 of these was inhibited by pre culturing North American soil with $A$. petiolata, and one species was enhanced. Of the 14 combinations of European mycorrhizal plant species and European soils, only one was inhibited by $A$. petiolata, whereas two species were enhanced. Likewise, pre-culturing North American soils with $A$. petiolata increased post-recruitment mortality of North American plant species from $6.2 \pm 1.9 \%$ to 20.9 $\pm 7.2 \%$ (Fig. 4). Pre-culturing European soils with $A$. petiolata had no effect on the mortality of European plant species.

Pre-culturing North American soil with A. petiolata also suppressed the final biomass of North American mycorrhizal plant species by an average of $59 \%$ over all species and sites, and the effect of $A$. petiolata was significant at all sites (Fig. 5). Pre-culturing soil from Germany with $A$. petiolata had no effect on the biomass of mycorrhizal plant species from that region, whereas pre-culturing soil from Spain with $A$. petiolata actually enhanced the biomass of plants from that region. In contrast to the strong inhibitory effect of $A$. petiolata on mycorrhizal plant species from North America, there was either no effect, or a positive effect, of $A$. petiolata soil culturing on the biomass of North American nonmycorrhizal plant species (Fig. 6). For the two European species that were non-mycorrhizal, A. petiolata training had no effect on their growth (Fig. 6).

Grouped comparisons of related taxa also demonstrated strong biogeographic differences among European and North American species while controlling for phylogenetic variation (Fig. 7). For Achillea millefolium, a circumboreal species, the biomass of North American plants grown in A. petiolata-cultured, North American soils was $56-100 \%$ lower than in non-cultured soils, and $A$. petiolata had strong effects on soil from all sites. For European A. millefolium, A. petiolata-culturing had no
TABle 2. List of species used in the Alliaria petiolata soiltraining experiment, with the presence or absence of arbuscular mycorrhizal (AM) fungal structures.

\begin{tabular}{lc}
\hline \hline \multicolumn{1}{c}{ Species } & AM fungal st \\
\hline A) North America & \\
Oregon & \\
Silene scouleri & +++ \\
Geum triflorum & -++ \\
Festuca roemeri & +++ \\
Elymus glaucus & --- \\
Poa secunda & +++ \\
Festuca occidentalis & -++ \\
Achillea millefolium & +++ \\
Montana & \\
Geum triflorum & \\
Festuca idahoensis & +++ \\
Pseudoroegneria spicata & +++ \\
Poa sandbergii & --+ \\
Achillea millefolium & +++ \\
Linum lewisii & ++ \\
Carex circinatum & \\
Carex vulpenoides & +++ \\
Vermont and Massachusetts & +++ \\
Geum triflorum & --- \\
Festuca idahoensis $\dagger$ & --- \\
Poa pratensis & \\
Elymus canadensis & \\
Achillea millefolium & \\
Pseudoroegneria spicata $\dagger$ & Linum perenne \\
Carex lurida & +++ \\
& +++ \\
& +++
\end{tabular}

Carex lurida

+++
-++
+++
---
+++
-++
+++


+++
+++
--+
+++
+++
+++
---
---


+++
+++
+++
---
+++
--+
-++
---

B) Europe

Germany

Silene diocia

Geum urbanum

Festuca ovina

Poa апnиa

Poa palustris

Agropyron repens

Achillea millefolium

Carex pendula

Spain

Silene diocia

Geum urbanum

Festuca scariosa

Poa annua

Poa palustris

Agropyron repens

Achillea millefolium

Linum austriacum

Centaurea melitensis

Carex pendula

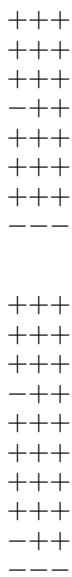

Notes: Symbols represent presence $(+)$ or absence $(-)$ of the following arbuscular mycorrhizal (AM) fungal structures (arbuscules, vesicles, hyphae, respectively) observed in their roots (e.g., "-++" denotes "arbuscules absent, vesicles present, hyphae present"). Plants without any AM fungal structures are considered not dependent on AM fungi for growth (even though they are sometimes found to be mycorrhizal in other studies, [e.g., Elymus spp.]). These species are not included in analyses in Figs. 2, 3, and 4. All seeds were collected from plants growing at the sites where soils where collected, with the exception of those marked with a dagger $(\dagger)$; these species were collected in Montana, within their natural distribution, but used with soils from Vermont and Massachusetts, which is outside their natural distribution. 


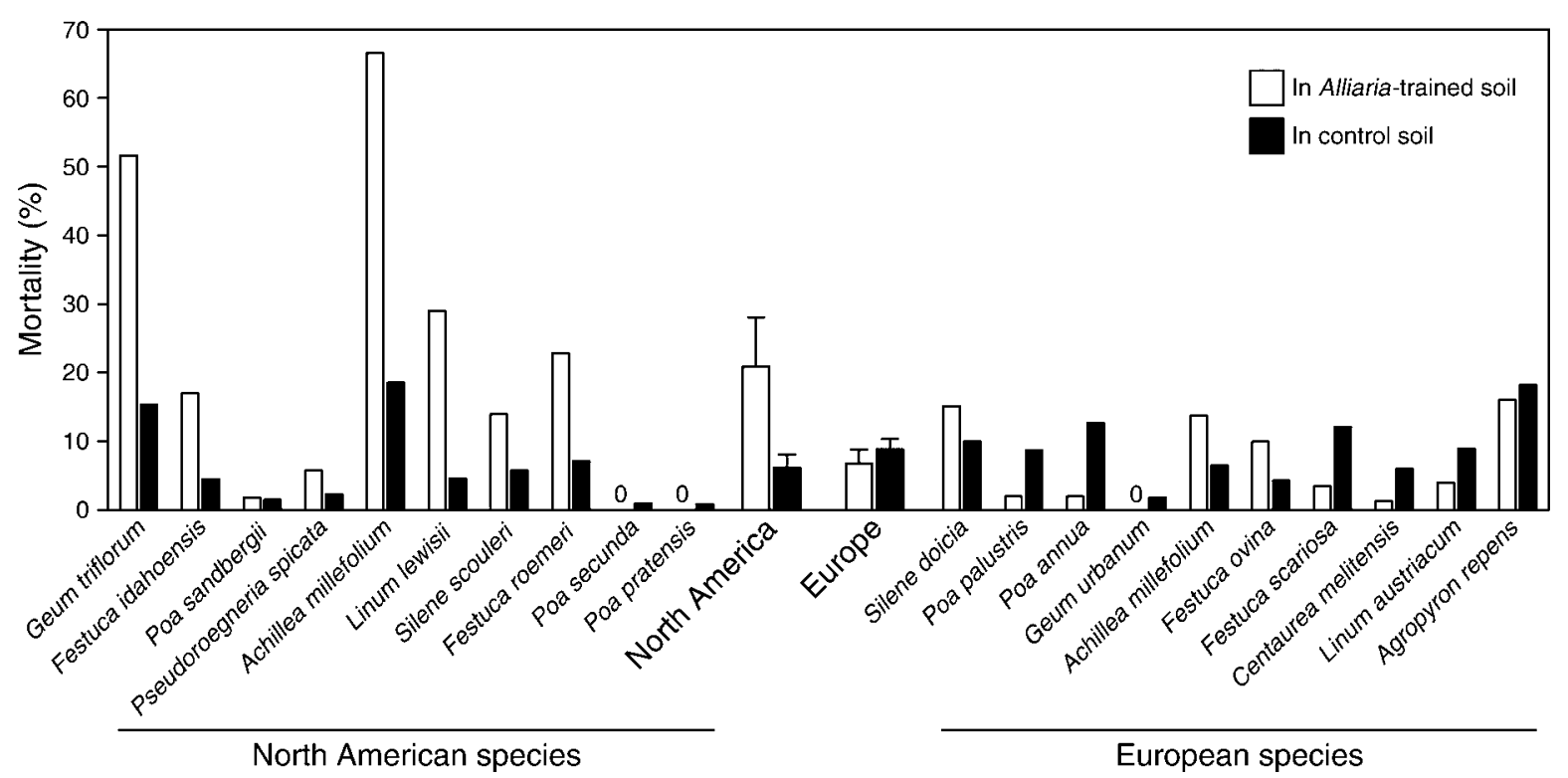

FIG. 4. The percentage of mortality of North American and European mycorrhizal plant species in native soil pre-trained with Alliaria petiolata and control soils. Thinner bars show the means for each species (replicate species from different sites are combined). Large bars in the center are means and $1 \mathrm{SE}$ for North American and Europe. Three-way ANOVA, for continent, $F_{1,4}=$ 23.369, $P=0.008$; for treatment, $F_{1,4}=40.754, P=0.003$; for continent $\times$ treatment, $F_{1,4}=112.368, P=0.0004$.

effect in German soils, but a significant inhibitory effect on A. millefolium in Spanish soils. Even so, A. petiolata culturing was more inhibitory to A. millefolium in North American soils than in European soils (continent $\times$ treatment, $F_{1,4}=11.437, P=0.028$ ). For North American species of Festuca, A. petiolata-culturing of North American soils caused a significant decline in biomass for Festuca from three of the four regions. There was no significant effect of $A$. petiolata-culturing of European soils on either European Festuca species. The North American Geum triflorum was highly inhibited in three of four North American populations (germination was too low in the Vermont populations for statistical analysis) by $A$. petiolata-culturing of North American soils, but $A$. petiolata-culturing of European soils had either no effect on Geum urbanum (German soils) or a positive effect (Spanish soils).

We found that some of the same flavonoids were present in both leaves and roots of $A$. petiolata plants (Appendix A: Fig. A1) could also be present in root exudates. The flavonoid fraction was enriched in glycosides, including alliarinoside, isovitexin- 6 "- $\beta$-D-glucopyranoside, and other flavonoid glycosides. The identities of these compounds were verified by electrospray ionization (ESI)/MS and MS/MS on a liquid chromatography quadrapole (LCQ) ion-trap mass spectrometer (ThermoQuest, San Jose, California, USA). Alliarinoside and isovitexin- 6 "- $\beta$-D-glucopyranoside are known from no other North American plant species. We also isolated a glucosinolate fraction devoid of these glycosides but enriched in glucosinolates, of which sinigrin and glucotropaeolin are known to predominate in A. petiolata (Vaughn and Berhow 1999) (Appendix B: Fig. B1).

The effects of $A$. petiolata extracts on AM fungal spore viability were weak when applied to European soils (Fig. 8), with all combinations of fractions causing decreases in spore viability ranging from $0 \%$ to $36 \%$ (Appendix C: Fig. C1). However, extracts had much stronger effects on AM fungal spore viability in North American soils (Fig. 8). The Alliaria fraction enriched in glucosinolates had weak effects on North American AM fungal spores, but the flavonoid glycoside-enriched fraction reduced North American spore viability by an average of $53 \%$, and the effect ranged from $41 \%$ to $71 \%$ (Appendix C: Fig. C1). When a combination of glucosinolate and flavonoid fractions were applied to North American soils, AM spore viability decreased by an average of $74 \%$, ranging from $53 \%$ to $89 \%$.

\section{Discussion}

We found that growing $A$. petiolata in soils from four different regions of North America decreased AM fungi, fungal diversity, and the emergence, growth, and survival of mycorrhizal plant species from the same regions. Non-mycorrhizal plant species did not show this response. Growing A. petiolata in soils from two different regions of Europe had no effect on AM fungi or soil fungal diversity, and had weak effects on the composition of fungal communities and plant emergence and growth. There was no indirect effect of $A$. petiolata on the survival of plant species from Europe. Application of $A$. petiolata leaf extracts that shared many chemical similarities with root extracts strongly suppressed AM fungi in soils from six North American 


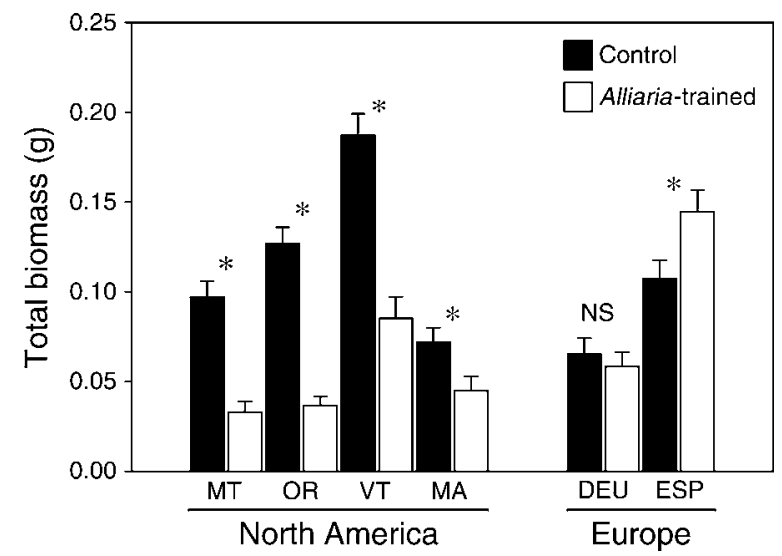

FIG. 5. Effect of pre-culturing soils with Alliaria petiolata on the final total biomass of North American and European mycorrhizal plant species grown in their native soils. Error bars show $1 \mathrm{SE}$. Three-way ANOVA, for continent, $F_{1,4}=0.217, P=$ 0.665 ; for treatment, $F_{1,4}=13.988, P=0.020$; for continent $\times$ treatment, $F_{1,4}=34.488, P=0.004$. Asterisks denote significant differences among treatment and control for a region as determined by separate $t$ tests, followed by a sequential Bonferroni correction for multiple tests $P<0.008$ ). See Fig. 1 for abbreviations.

sites, but had no effects on AM fungi in soils from six European sites. Moreover, extract concentrations used here were lower than in any other study of allelopathy in A. petiolata (e.g., Stinson et al. 2006). These results suggest that the long history of coexistence between $A$. petiolata, soil fungi, and other plant species in Europe, where A. petiolata is native, has led to the evolution of resistance in soil fungi that promote coexistence among A. petiolata and fungi and, therefore, A. petiolata and other plant species (i.e., Callaway et al. 2005). In contrast, it appears that $A$. petiolata may produce a biochemical (or suite of biochemicals) that is novel in North America and to which North American plants and fungi are not adapted, supporting the novel weapons hypothesis (Callaway and Ridenour 2004).

In addition to the novel glycosides considered in this study, $A$. petiolata has recently been identified as markedly cyanogenic, making it unique among Brassicaceous plants in which cyanogenesis has been examined (Cipollini and Gruner 2007). However, our evidence for the novelty of $A$. petiolata biochemistry is indirect, because we cannot compare all aspects of plant chemistry among $A$. petiolata and North American native mustard species. Whether or not North American Brassicaceous species also suppress soil fungi remains an area of further study.

The fact that $A$. petiolata had some positive effects on European species (i.e., emergence in Achillea millefolium and Silene diocia [Fig. 4] and total biomass in native plants from Spain [Fig. 5]) is curious and warrants further study. Because plants vary in their dependence upon mycorrhizal symbiosis for growth (Klironomos 2002), species that are less-dependent on AM fungi may be released from competition via $A$. petiolata's suppression of their more mycorrhizae-dependent neighbors (see Stinson et al. 2006). Alternatively, some European plants could be released from the effects of harmful fungi, bacteria, or other microbes via the phytochemical effects of $A$. petiolata on these soil organisms. Alliaria petiolata may also affect soil chemistry in ways that alter $\mathrm{pH}$, nutrient availability, or other aspects of plant-soil interactions that favor some species over others.

Our results cannot be interpreted as supportive of species-specific relationships among plant-AM fungi within continents, primarily because we were not able
FIG. 6. Effect of pre-culturing soils with Alliaria petiolata on the final biomass of North American non-mycorrhizal plants. Plant species were grown in soils from general areas in which seeds were acquired. Error bars show 1 SE. For continent, $F_{1,1}=24.141, P=0.136$; for treatment, $F_{1,4.9}=18.967, P=0.008$; for continent $\times$ treatment, $F_{1,1}=28.286, P=0.118$. See Fig. 1 for abbreviations.

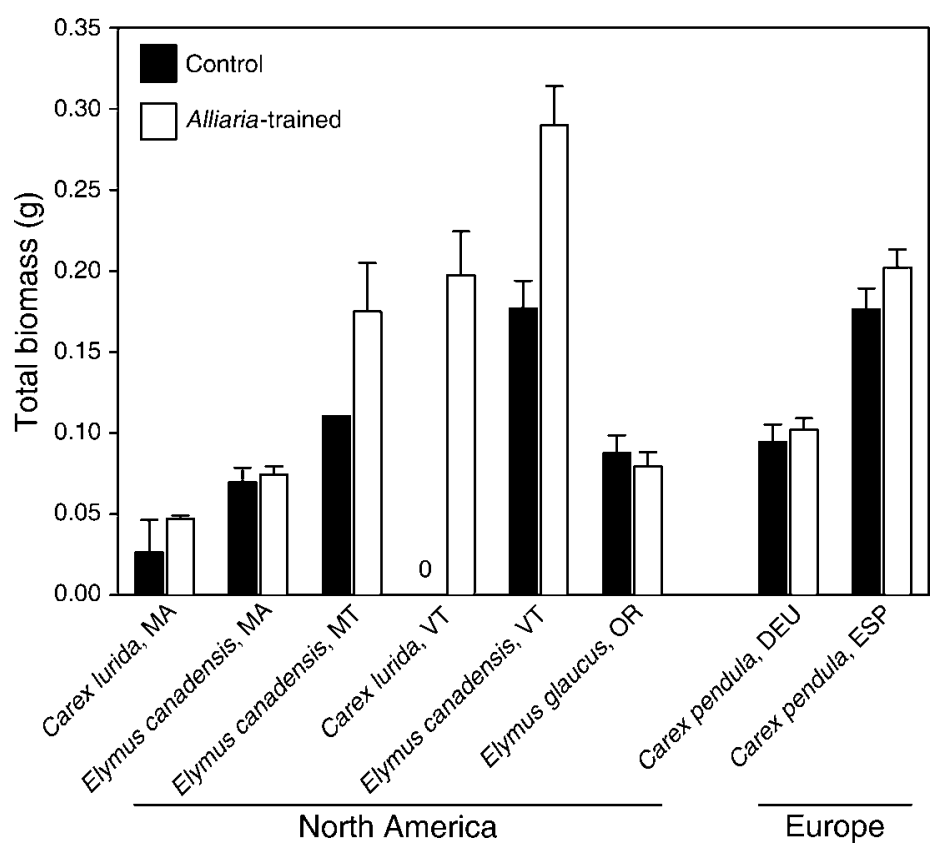



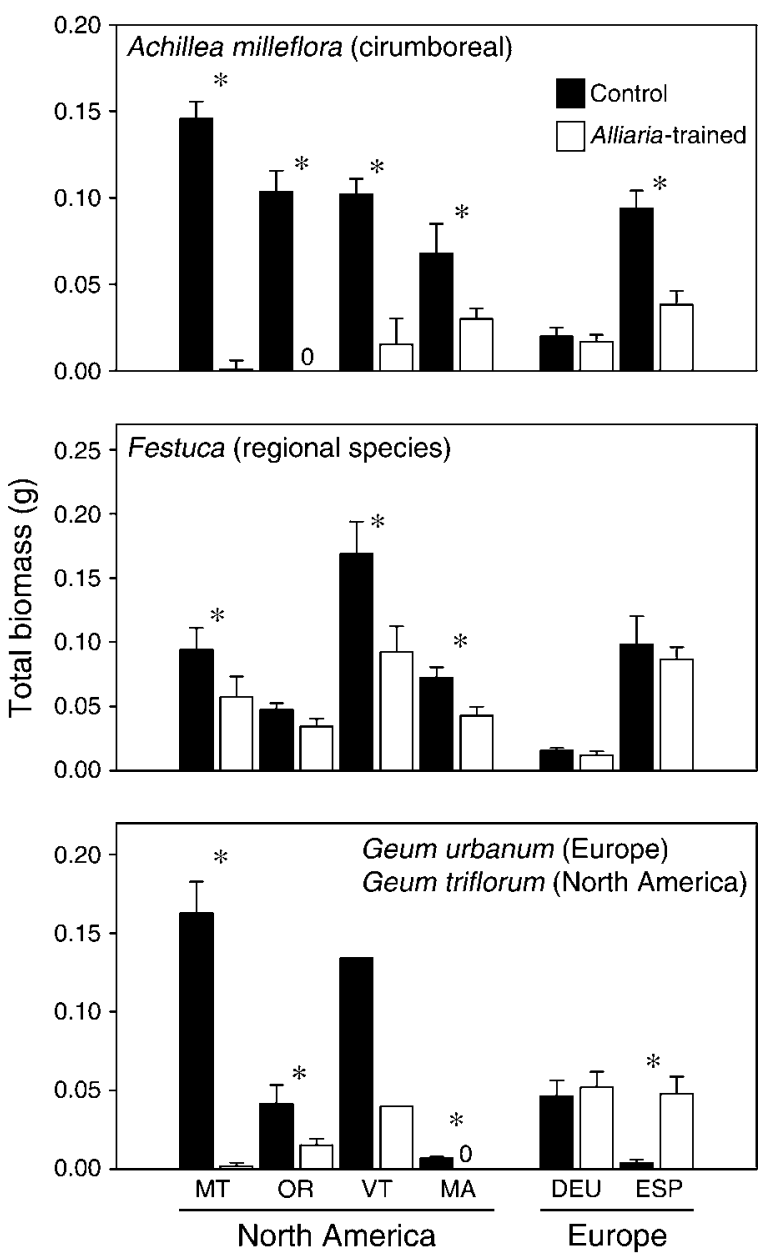

FIG. 7. Phylogenetically controlled (within genus or within circumboreal species) comparisons of the effect of Alliaria petiolata pre-culturing of soils. Bars show means for a given species at a given region with error bars representing $1 \mathrm{SE}$. For Achillea; for continent, $F_{1,4}=0.244, P=0.647$; for treatment, $F_{1,4}=26.391, P=0.007$; for continent $\times$ treatment, $F_{1,4}=$ 11.437, $P=0.028$. For Festuca; for continent, $F_{1,4}=0.194, P=$ 0.683 ; for treatment, $F_{1,4}=3.600, P=0.458$; for continent $\times$ treatment, $F_{1,4}=21.154, P=0.010$. For Geum; for continent, $F_{1,3}=0.230, P=0.656$; for treatment, $F_{1,3}=0.836, P=0.412$; for continent $\times$ treatment, $F_{1,3}=6.495, P=0.063$. Asterisks denote significant differences $(P<0.05)$ among treatment and control for a region as determined by separate $t$ tests, followed by a sequential Bonferroni correction for multiple tests within a species $P<0.008)$. See Fig. 1 for abbreviations.

to match soils with large numbers of species at the smaller scale of local habitats. For example, S. scouleri, G. triflorum, F. roemeri, A. millefolium, L. perenne, and L. lewisii can be found in the precise habitats invaded by $A$. petiolata, and these species fit the general pattern reported here for greater $A$. petiolata inhibition in North America. In contrast, $F$. idahoensis, $P$. spicata, and $P$. sandbergii are generally found in drier and more open habitats than those invaded by $A$. petiolata, but these species also fit the general pattern we report for North American soils in our experiments. Similarly, $S$. diocia, G. urbanum, F. ovina, F. scariosa, P. palustris, A. millefolium, and L. austriacum occur in the same natural European habitats as A. petiolata, and these species fit the general pattern of being weakly inhibited by Alliaria as reported for European soils in our experiments. But Agropyron repens and Роа аппиа are from more xeric habitats than $A$. petiolata, and these species also fit the general pattern reported from Europe. Therefore, $A$. petiolata does not appear to disrupt relationships among plants and AM fungi in a highly species-specific manner. Instead we interpret our results as $A$. petiolata simply killing non-adapted North American AM fungi, and this has negative consequences for any plant species that might be dependent on a broad spectrum of AM fungal species; the inhibition of North American AM fungi may even suppress mycorrhizal plants from Europe if the two groups were combined. Local-scale relationships may exist among AM fungi and plants, but our experiments were not designed to test this possibility.

The biogeographical differences in the effect of $A$. petiolata were likely due to plant biochemistry. First, the effects we report for soil culturing by A. petiolata and for soil biochemical fractions were manifest in the absence of living A. petiolata plants, and therefore, A. petiolata could not have been competing with native plants for resources. Second, the effects of specific plant extracts had very similar effects as training soils with $A$. petiolata; reducing the viability of North American AM fungi, but not the viability of European AM fungi.

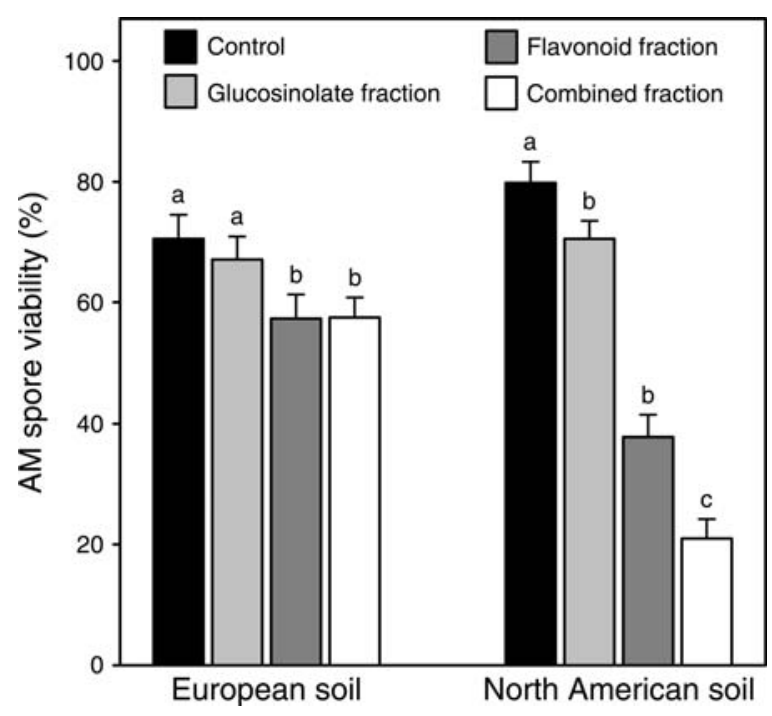

FIG. 8. Effect of root exudate fractions from Alliaria petiolata on the viability of arbuscular mycorrhizal (AM) fungi in soils from six sites in Europe and six sites in North America, with regions combined (see Appendix C: Fig. C1). In a threeway ANOVA with five replicates per region; for continent, $F_{1,10}$ $=9.810, P=0.035$; for region, $F_{10,192}=1.924, P=0.044$; for treatment, $F_{3,30}=47.798, P=0.002$; for continent $\times$ treatment, $F_{3,30}=18.385, P=0.013$, for continent $\times$ treatment, $F_{30,1924}=$ $0.978, P=0.501$. 
Our evidence for $A$. petiolata's inhibition of North American species through suppression of AM fungi does not preclude other processes as drivers of $A$. petiolata invasion. A. petiolata also has strong direct competitive and allelopathic effects (Meekins and McCarthy 1999, Bossdorf et al. 2004, Prati and Bossdorf 2004); therefore, these direct effects are also important mechanisms by which $A$. petiolata affects other plant species. Neither previous studies nor ours have fully tested potential biogeographic differences in direct plant-plant interactions; however, plants from North American A. petiolata populations are not better intra-specific competitors than plants from Europe (Bossdorf et al. 2004), suggesting that direct effects may not show the biogeographic differences necessary to explain superior performance in invaded regions where $A$. petiolata is exotic. Disturbance is also a factor in the spread of $A$. petiolata (Nuzzo 1999), but there is no evidence to suggest that $A$. petiolata responds to disturbance in North America differently than in Europe. However, invasive European earthworms may have more powerful effects in North American forests than in their native forests, and there are clear spatial relationships between A. petiolata invasion and the presence of European earthworms in North American forests (B. Blossey and J. Maerz, personal communication). The effects of European earthworms may ultimately prove to be a strong driver of $A$. petiolata invasion, and are likely to interact with the biochemical mechanisms presented in this paper.

Non-mycorrhizal plant families represent a disproportionate number of invasive plants globally, relative to the available species pool (Pyšek 1998), suggesting that suppression of local AM fungi has the potential to be a general process, but this remains to be seen. Other research has provided evidence for the novel weapons hypothesis by showing that novel biochemicals produced by exotic invasive plants have stronger toxic effects on other plants in invaded communities than on plants in the communities where the invader originated (Callaway and Aschehoug 2000, Vivanco et al. 2004, Thorpe 2006, but see Blair et al. 2005, 2006), and that changes in plant-soil microbe interactions can contribute to plant invasions (Van der Putten et al. 1988, Reinhart et al. 2003, Agrawal et al. 2005, Reinhart and Callaway 2006). We show that an invader can suppress naïve native mutualists and, by doing so, indirectly inhibit a number of native plants that rely on these mutualisms. By transporting organisms far beyond their historical dispersal limitations, humans may have mixed plant and microbial species that do not share common evolutionary trajectories (Callaway et al. 2005). This mixing appears to have profound negative consequences for invaded communities.

\section{ACKNOWLEDGMENTS}

Funding was provided by DoD SERDP, the Aldo Leopold Wilderness Center, the USDA-IPM and USDA-NRICP, the National Science Foundation, The University of Montana
Sponsored Research Office, the EPA GRO program, Wright State University, and the Civilian Research and Development Foundation, and the Natural Sciences and Engineering Research Council of Canada.

\section{Literature Cited}

Agrawal, A. A., P. M. Kotanen, C. E. Mitchell, A. G. Power, W. Godsoe, and J. Klironomos. 2005. Enemy release? An experiment with congeneric plant pairs and diverse above- and belowground enemies. Ecology 86:2979-2989.

Bais, H. P., R. Vepachedu, S. Gilroy, R. M. Callaway, and J. M. Vivanco. 2003. Allelopathy and exotic plants: from genes to invasion. Science 301:1377-1380.

Baskin, J. M., and C. C. Baskin. 1992. Seed-germination biology of the weedy biennial Alliaria petiolata. Natural Areas Journal 12:191-197.

Beckstead, J., and I. M. Parker. 2004. Invasiveness of Ammophila arenaria: release from soil-borne pathogens? Ecology 84:2824-2831.

Bever, J. D. 2003. Soil community feedback and the coexistence of competitors: conceptual frameworks and empirical tests. New Phytologist 157:465-473.

Blair, A. C., S. J. Nissen, G. R. Brunk, and R. A. Hufbauer. 2006. A lack of evidence for an ecological role of the putative allelochemical $( \pm)$-catechin in spotted knapweed invasion success. Journal of Chemical Ecology. [doi: 10.1007/ 210886-006-9168-y]

Blair, A. C., B. D. Hanson, G. R. Brunk, R. A. Marrs, P. Westra, S. J. Nissen, and R. A. Hufbauer. 2005. New techniques and findings in the study of a candidate allelochemical implicated in invasion success. Ecology Letters 8:1039-1047.

Blossey, B., and R. Nötzold. 1995. Evolution of increased competitive ability in invasive non-indigenous plants: a hypothesis. Journal of Ecology 83:887-889.

Bossdorf, O., D. Prati, H. Auge, and B. Schmid. 2004. Reduced competitive ability in an invasive plant. Ecology Letters 7: 346-353.

Brundrett, M. C., Y. Piche, and R. L. Peterson. 1984. A new method for observing the morphology of vesicular-arbuscular mycorrhizae. Canadian Journal of Botany 62:2128-2134.

Callaway, R. M., and E. T. Aschehoug. 2000. Invasive plants versus their new and old neighbors: a mechanism for exotic invasion. Science 290:521-523.

Callaway, R. M., J. L. Hierro, and A. S. Thorpe. 2005. Evolutionary trajectories in plant and soil microbial communities: Centaurea invasions and the geographic mosaic of coevolution. Pages 341-363 in D. F. Sax, S. D. Gaines, and J. J. Stachowicz, editors. Exotic species invasions: insights into ecology, evolution and biogeography. Sinauer, Sunderland, Massachusetts, USA.

Callaway, R. M., and W. M. Ridenour. 2004. Novel weapons: a biochemically based hypothesis for invasive success and the evolution of increased competitive ability. Frontiers in Ecology and the Environment 2:436-433.

Callaway, R. M., G. Thelen, A. Rodriguez, and W. E. Holben. 2004. Release from inhibitory soil biota in Europe and positive plant-soil feedbacks in North America promote invasion. Nature 427:731-733.

Cappuccino, N., and J. T. Arnason. 2006. Novel chemistry of invasive exotic plants. Biology Letters 2:189-193.

Carvalho, L. M., P. M. Correia, and M. A. Martins-Loucao. 2004. Arbuscular mycorrhizal fungal propagules in a salt marsh. Mycorrhiza 14:165-170.

Cipollini, D., and B. Gruner. 2007. Cyanide in the chemical arsenal of garlic mustard, Alliaria petiolata. Journal of Chemical Ecology 33:85-94.

Cipollini, D., J. Mbagwu, K. Barto, C. Hillstrom, and S. Enright. 2005. Expression of constitutive and inducible chemical defenses in native and invasive populations of Alliaria petiolata. Journal of Chemical Ecology 31:1255-1267. 
Clapham, A. R., et al. 1952. The flora of the British Isles Cambridge University Press, Cambridge, UK.

DeWalt, S. J., J. S. Denslow, and K. Ickes. 2004. Naturalenemy release facilitates habitat expansion of the invasive tropical shrub Clidemia hirta. Ecology 85:471-483.

Dhillion, S. S., and R. C. Anderson. 1999. Growth and photosynthetic response of first-year garlic mustard (Alliaria petiolata) to varied irradiance. Journal of the Torrey Botanical Society 126:9-14.

Don, R. H., P. T. Cox, B. J. Wainwright, K. Baker, and J. S. Mattick. 1991. Touchdown PCR to circumvent spurious priming during gene amplification. Nucleic Acids Research 19:4008.

Elton, C. S. 1958. The ecology of invasions by animals and plants. Methuen Press, London, UK.

Gardiner, J. B., M. J. Morra, C. V. Eberlein, P. D. Brown, and V. Borek. 1999. Allelochemicals released in soil following incorporation of rapeseed (Brassica napus) green manures. Journal of Agricultural Food Chemistry 47:3837-3842.

Haribal, M., and J. A. A. Renwick. 2001. Seasonal and population variation in flavonoid and alliarinoside content of Alliaria petiolata. Journal of Chemical Ecology 27:15851594.

Hierro, J. L., J. L. Maron, and R. M. Callaway. 2005. A biogeographic approach to plant invasions: the importance of studying exotics in their introduced and native range. Journal of Ecology 93:5-15.

Johnson, N. C., J. H. Graham, and F. A. Smith. 1997. Functioning of mycorrhizal associations along the mutualism-parasitism continuum. New Phytologist 135:575-585.

Keane, R. M., and M. J. Crawley. 2002. Exotic plant invasions and the enemy release hypothesis. Trends in Ecology and Evolution 4:164-170.

Kiddle, G., R. N. Bennett, N. P. Botting, N. E. Davidson, A. A. B. Robertson, and R. M. Wallsgrove. 2001. Highperformance liquid chromatographic separation of natural and synthetic desulphoglucosinolates and their chemical validation by UV, NMR and chemical ionisation-MS methods. Phytochemical analysis 12:226-242.

Kim-Jong, S., M. Sakai, A. Hosoda, and J. S. Kim. 1999. Application of DGGE analysis to the study of bacterial community structure in plant roots and in nonrhizosphere soil. Soil Science and Plant Nutrition 45:493-497.

Klironomos, J. 2002. Feedback with soil biota contributes to plant rarity and invasiveness in communities. Nature 417: $67-70$.

Klironomos, J. N., P. Moutoglis, B. Kendrick, and P. A. Widden. 1993. Comparison of spatial heterogeneity of vesicular-arbuscular mycorrhizal fungi in two maple-forest soils. Canadian Journal of Botany 71:1472-1480.

Mallik, A. U., and F. Pellissier. 2000. Effects of Vaccinium myrtillus on spruce regeneration: testing the notion of coevolutionary significance of allelopathy. Journal of Chemical Ecology 26:2197-2209.

McCarthy, B. C., and S. L. Hanson. 1998. An assessment of the allelopathic potential of the invasive weed Alliaria petiolata (Brassicacea). Castanea 63:68-73.

McGonigle, T. P., M. H. Miller, D. G. Evans, G. L. Fairchild, and J. A. Swan. 1990. A new method which gives an objective measure of colonization of roots by vesicular-arbuscular mycorrhizal fungi. New Phytology 115:495-501.

Meekins, J. F., and B. C. McCarthy. 1999. Competitive ability of Alliaria petiolata (garlic mustard, Brassicaceae), an invasive, nonindigenous forest herb. International Journal of Plant Science 160:743-752.

Meekins, J. F., and B. C. McCarthy. 2000. Responses of the biennial forest herb $A$. petiolata to variation in population density, nutrient addition and light availability. Journal of Ecology 88:447-463.

Meekins, J. F., and B. C. McCarthy. 2001. Effect of environmental variation on the invasive success of a nonindigenous forest herb. Ecological Applications 11: $1336-1348$.

Morra, M. J., and J. A. Kirkegaard. 2002. Isothiocyanate release from soil-incorporated Brassica tissues. Soil Biology and Biochemistry 34:1683-1690.

Muyzer, G., S. Hottentrager, A. Teske, and S. Wawer. 1996. Denaturing gradient gel electrophoresis of PCR-amplified 16S rDNA - a new molecular approach to analyze the genetic diversity of mixed microbial communities. Pages $1-23$ in A. Akkermans, J. D. van Elsas, and F. J. de Bruijn, editors. Molecular microbial ecology manual. Kluwer Academic Publishers, Lowell, Massachusetts, USA.

Nuzzo, V. A. 1991. Experimental control of Garlic Mustard [Alliaria petiolata (Bieb.) Cavara \& Grande] in Northern Illinois using fire, herbicide and cutting. Natural Areas Journal 11:158-167.

Nuzzo, V. A. 1999. Invasion pattern of the herb garlic mustard (Alliaria petiolata) in high quality forests. Biological Invasions 1:169-179.

Nuzzo, V. A. 2000. Element stewardship abstract for Alliaria petiolata. The Nature Conservancy, Arlington, Virginia, USA.

Packer, A., and K. Clay. 2000. Soil pathogens and spatial patterns of seedling mortality in a temperate tree. Nature 404: 278-281.

Philippot, L., and J. C. Germon. 2005. Contribution of bacteria to initial input and cycling of nitrogen in soils. Pages 159-176 in F. Buscot and A. Varma, editors, Microorganisms in soils: roles in Genesis and Functions. Springer-Verlag, Berlin, Germany.

Prati, D., and O. Bossdorf. 2004. Allelopathic inhibition of germination by Alliaria petiolata (Brassicaceae). American Journal of Botany 91:285-288.

Pyšek, P. 1998. Is there a taxonomic pattern to plant invasions? Oikos 82:282-294.

Rabotnov, T. A. 1982. Importance of the evolutionary approach to the study of allelopathy. Ékologia 3:5-8. Translated from Russian.

R Development Core Team. 2004. R: a language and environment for statistical computing. R Foundation for Statistical Computing, Vienna, Austria. 〈http://www. r-project.org

Reinhart, K. O., and R. M. Callaway. 2006. Tansley review: soil biota and invasive plants. New Phytologist 170:445-457.

Reinhart, K. O., A. Packer, W. H. van der Putten, and K. Clay. 2003. Plant-soil biota interactions and spatial distribution of black cherry in its native and invasive ranges. Ecology Letters 6:1046-1050.

Roberts, K. J., and R. C. Anderson. 2001. Effect of garlic mustard [Alliaria petiolata (Beib. Cavara \& Grande)] extracts on plants and arbuscular mycorrhizal (AM) fungi. American Midland Naturalist 146:146-152.

Sheffield, V. C., D. R. Cox, L. S. Lerman, and R. M. Meyers. 1989. Attachment of a 40 base-pair $\mathrm{G}+\mathrm{C}$-rich sequence (GC clamp) to genomic DNA fragments by the polymerase chain reaction results in improved detection of single-base changes. Proceedings National Academy Science USA 86:232-236.

Sorenson, T. 1948. A method of establishing groups of equal amplitude in plant sociology based on similarity of species content. Kongelige Danske Videnskabernes Selskab 5:1-34.

Stinson, K. A., S. A. Campbell, J. R. Powell, B. E. Wolfe, R. M. Callaway, G. C. Thelen, S. G. Hallett, D. Prati, and J. N. Klironomos. 2006. Invasive plant suppresses the growth of native tree seedlings by disrupting belowground mutualisms. Public Library of Science Biology. 4(5):e140 [doi: 10. 1371/journal.pbio.0040140]

Thorpe, A. S. 2006. Biochemical effects of Centaurea maculosa on soil nutrient cycles and plant communities. Dissertation. University of Montana, Missoula, Montana, USA.

Torsvik, V., and L. Øvreås. 2004. Microbial diversity and function in soil: from genes to ecosystems. Current Opinion Microbiology 5:240-245. 
Van der Putten, W. H., C. Van Dijk, and S. R. Troelstra. 1988. Biotic soil factors affecting the growth and development of Ammophila arenaria. Oecologia 76:313-320.

Van der Putten, W. H., G. W. Yeates, H. Duyts, C. S. Reis, and G. Karssen. 2005. Invasive plants and their escape from root herbivory: a worldwide comparison of the root-feeding nematode communities of the dune grass Ammophila arenaria in natural and introduced ranges. Biological Invasions 7: $733-746$.

Vaughn, S. F., and M. A Berhow. 1999. Allelochemicals isolated from tissues of the invasive weed garlic mustard (Alliaria petiolata). Journal of Chemical Ecology 25: 2495-2504.

Vivanco, J. M., H. P. Bais, F. R. Stermitz, G. C. Thelen, and R. M. Callaway. 2004. Biogeographical variation in commu- nity response to root allelochemistry: novel weapons and exotic invasion. Ecology Letters 7:285-292.

Vitousek, P. M., L. R. Walker, L. D. Whiteaker, D. MuellerDombois, and P. A. Matson. 1987. Biological invasion by Myrica faya alters ecosystem development in Hawaii. Science 238:802-804.

Welk, E., and K. Schubert. 2002. Present and potential distribution of invasive garlic mustard (Alliaria petiolata) in North America. Diversity and Distributions 8:219-233.

White, T. J., T. Bruns, S. Lee, and J. Taylor. 1990. Amplification and direct sequencing of fungal ribosomal RNA genes for phylogenetics. Pages 315-322 in M. A. Innis, D. H. Gelfand, J. J. Sninsky, and T. J. White, editors. PCR protocols: a guide to methods and applications. Academic Press, San Diego, California, USA.

\section{APPENDIX A}

HPLC chromatographs from Alliaria petiolata leaves and roots (Ecological Archives XXX).

\section{APPENDIX B}

Representative HPLC chromatographs of fractionated garlic mustard extracts (Ecological Archives XXX).

\section{APPENDIX C}

Effect of root exudate fractions from Alliaria petiolata on the viability of AM fungi in soils from six sites in Europe and six sites in North America (Ecological Archives XXX). 